\title{
The Existing Forms of Denitrifiable Reductive Groups in Sludge
}

Kang Yang ${ }^{1}$, Hui Li ${ }^{* 1}$, Fang Dang ${ }^{1}$, Ji Zou ${ }^{2}$, Songzhu Zhang ${ }^{3}$

${ }^{1}$ College of Materials Science and Engineering, Xi' an University of Architecture and Technology, Xi'an 710055, China

${ }^{2}$ Xi'an Research and Design Institute of Wall\&Roof Materials

Xi'an 710061, China

${ }^{3}$ Monalisa Architectural Ceramics Co., Ltd, Qingyuan 511533, China

*to whom all correspondence should be addressed: e-mail: sunshineli@vip.sina.com

GRAPHICAL ABSTRACT

\begin{tabular}{lllll}
\hline & Mass $(\mathrm{g})$ & $\begin{array}{l}\text { Moisture } \mathrm{M}_{\mathrm{d}} \\
(\%)\end{array}$ & $\begin{array}{l}\mathrm{Ash} \text { content } \\
\mathrm{A}_{\mathrm{d}}(\%)\end{array}$ & $\begin{array}{l}\text { Volatile content } \\
\mathrm{V}_{\mathrm{d}}(\%)\end{array}$ \\
\hline $\begin{array}{l}\text { Measured } \\
\text { value }\end{array}$ & 0.98 & 4.43 & 25.53 & 63.53 \\
\hline
\end{tabular}

\begin{abstract}
As a solid sediment produced in the process of sewage treatment, sludge is an extremely complex heterogeneous body composed of organic debris, bacterial cells, inorganic particles, and colloids. However, it has a certain calorific value and it will pyrolyze and release reducing gases such as $\mathrm{NH}_{3}, \mathrm{CH}_{4}, \mathrm{CO}$, and $\mathrm{HCN}$ during the heating process which means it theoretically has a certain cooperative denitrification ability. If the above two characteristics of sludge can be combined, the dual purpose of denitration and emission reduction can be achieved while the heat value is recovered (Sheng et al., 2004.; Xiuru et al., 2010.; Huan et al., 2014.; Zhichao et al., 2012.). Since the structural components of sludge are very complex, it is difficult to directly study the sludge body and analyze the occurrence of internal reducing groups due to the overlapping interference of many organic functional groups due to the complexity of sludge structural components. Therefore, this article designed a "gradient dropping pyrolysis coupled nuclear magnetic resonance test technology" to conduct an in-depth analysis of the existence of reducing groups in the sludge, and the research results show that: the structure of the functional group that may be converted into reducing group like HCN, NH3, $\mathrm{CO}, \mathrm{CH}_{\mathrm{i}}$ are $\mathrm{CH} 3 \mathrm{~N}=$, $\mathrm{RCH} 2-\mathrm{S}-, \mathrm{RCH} 2-\mathrm{N}=$, RCH2-O-, R2CH-N=, R2CH-S-, which mainly release during the temperature of $300 \sim 400^{\circ} \mathrm{C}$.
\end{abstract}

Keywords: Sludge, reductive groups, gradient dropping, NMR, reducing group.

\section{Introduction}

Sludge is a semi-solid or solid substance produced in the process of sewage treatment. It has high water content, high organic content, easily decomposes and smells, and has fine particles, small specific gravity, and a colloidal liquid state. The sludge itself has a certain calorific value $(>1500 \mathrm{kCal} / \mathrm{kg})$, and during the heating process, it will thermally interpret and release reducing gases such as $\mathrm{NH}_{3}, \mathrm{CH}_{4}, \mathrm{CO}$, and $\mathrm{HCN}$. 
Some engineering practices show that the co-processing of sludge in cement kilns can help reduce NOx emissions during the process of calcining cement clinker, and the NOx removal effect is more significant when the sludge is added in a cement precalcining furnace (Ping et al., 2015.). The combustion of sludge can produce more reducing gases $\left(\mathrm{HCN}, \mathrm{NH}_{3}, \mathrm{CO}\right.$, and $\mathrm{CH}_{4}$ ), especially when $\mathrm{NH}_{3}$ plays a leading role in the reduction of NOx, which means the combustion of sludge can reduce NOx (Dong et al.,2016; Ping et al.,2019; Xiang et al.,2019). These studies basically proved the reduction effect of $\mathrm{NH}_{3}$ on NO. Under low oxygen conditions, the generated $\mathrm{NH}_{3}$ reacts with $-\mathrm{OH}$ and $-\mathrm{O}$ to form a large number of nitrogen-containing $\left(\mathrm{NH}_{\mathrm{i}}\right)$ radicals, which can effectively reduce $\mathrm{NO}$ (Weiyi et al., 2019.). Therefore, it is very important to study the occurrence form of reducing gases such as $\mathrm{HCN}, \mathrm{NH}_{3}, \mathrm{CO}$ and $\mathrm{CH}_{4}$ in sludge, as well as the temperature range and release characteristics of the thermal migration of these reducing groups.

The complexity of sludge structure and the process of sludge combustion to reduce $\mathrm{NO}_{\mathrm{x}}$, which involves the source of reducing gas, the homogeneous reaction of reducing gas and $\mathrm{NO}_{\mathrm{x}}$ and the heterogeneous reaction of sludge coke and $\mathrm{NO}_{\mathrm{x}}$ makes it more difficult to study. Under these difficulties, researcher Han Lipeng et al. (Lipeng et al., 2018) first mixed the sludge with coal and crushed it using a crusher, after which it was charged into a circulating fluidized bed boiler for combustion and denitration. Ultra-low emissions were stably achieved while the consumption of denitrifiers in the original selective non-catalytic reduction system decreased significantly, saving $37.6 \%$ of the denitrifier and achieving an ideal auxiliary denitrification effect. Wang Zhiqiang et al. (Zhiqiang et al., 2010) studied the reduction of sludge coke $\mathrm{NO}_{\mathrm{x}}$ by the heterogeneous reaction. They obtained that the reducing ability of sludge coke to $\mathrm{NO}_{\mathrm{x}}$ depends on its physicochemical properties, including specific surface area, pore structure, and chemical composition, and these properties depend on the pyrolysis conditions of the sludge (Feng et al., 2020; He et al., 2018). However, these studies only focused on the feasibility analysis of sludge reburning and denitration or the mechanism of sludge coke reduction. Due to the extremely complex composition of the sludge, the current analysis and testing techniques cannot identify and characterize the constituents one by one, however, there is no clear research on reducing gases to make the precursor to what form they occur in the sludge (Chen et al., 2017).

This paper designs a "gradient dropping pyrolysis method" based on the gradient dropping pyrolysis method coupled with nuclear magnetic resonance technology. The core of this technology is to use the change of pyrolysis products of sludge at different temperatures to determine whether the sludge contains reductive organic components, that is, precursors that can react with $\mathrm{NO}_{\mathrm{X}}$.

The structural components in the sludge are very complex, so it is difficult to clearly analyze the occurrence form of these reducing groups. However, the organic groups in the sludge have the characteristics of migration and release at a specific temperature and the higher temperature the of the organic groups, the more types and quantities of group migration and release. So this experiment uses coal industry analyzer to measure the moisture, ash, and volatile contents of the sludge powder, uses x-ray diffraction analyzer to determine the mineral composition of the sludge powder, uses synchronous thermal analyzer to carry out the gradient final-temperature pyrolysis thermal analysis, and uses NMR spectrometer to analyze the forms of sludge and analyze their reducibility.

\section{Experiment}

\subsection{Sludge gradient dropping pyrolysis}

In this experiment, by setting a number of gradient final temperatures under an inert atmosphere, the sludge can be pyrolyzed at high temperature to eliminate the overlapping interference caused by organic groups in the sludge, so that most of the organic groups are converted into gaseous form and released. We collected 
TGA and DSC thermal analysis data at different final temperatures, and use nuclear magnetic resonance technology to analyze the residual organic group structure at different final temperatures. Also, the higher the pyrolysis temperature, the simpler the organic components in the sludge. Therefore, combined with the above experimental results, the NMR spectrum inversion method (Dong et al., 2007), which gradually reduce the pyrolysis temperature by a certain gradient to gradually change the type and quantity of the remaining organic groups, was used to sequentially compare the increase and decrease in the organic functional groups at the two final temperatures, before and after, in order to analyze whether the organic component is contained in the sludge and also to determine if it has reducing properties to study the occurrence of reductive groups in the sludge. The process are as follows:

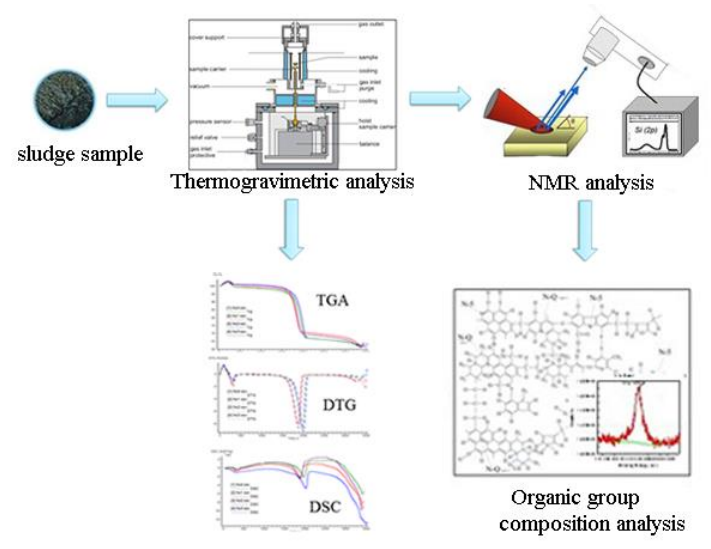

Figure 1. Schematic diagram of gradient dropping pyrolysis method coupled with nuclear magnetic resonance testing technology

\subsection{Preparation of sludge sample}

The raw materials for the experiment were mud cakes from the Xi'an Chuangye Water Company's sludge filter press dehydration. First, a certain amount of the mud cakes was placed in an oven and dried at $105{ }^{\circ} \mathrm{C}$ until the weighing before and after two times remained basically the same. The moisture content of the raw material was $81.82 \%$. Then, a ZHM-1 prototype was used to pulverize the drying sludge, and it was homogenized with a divider. Sludge powder with an average particle size of $29.98 \mathrm{~m}$ was obtained and sealed in a dryer.

\subsection{Characterization of the physical and chemical properties of the sludge sample}

The coal industry analyzer (Model: SDTGA5000, Jinan Oulaide Instrument Co., Ltd.) was used to measure the moisture, ash, and volatile contents of the sludge powder. The results are shown in Table 1.

Table 1. Water, ash, and volatile contents of the sludge powder

\begin{tabular}{lllll}
\hline & Mass $(\mathrm{g})$ & $\begin{array}{l}\text { Moisture } \mathrm{M}_{\mathrm{d}} \\
(\%)\end{array}$ & $\begin{array}{l}\text { Ash content } \\
\mathrm{A}_{\mathrm{d}}(\%)\end{array}$ & $\begin{array}{l}\text { Volatile content } \\
\mathrm{V}_{\mathrm{d}}(\%)\end{array}$ \\
\hline $\begin{array}{l}\text { Measured } \\
\text { value }\end{array}$ & 0.98 & 4.43 & 25.53 & 63.53 \\
\hline
\end{tabular}

The carbon, hydrogen, oxygen, nitrogen, and sulfur contents of the sludge powder were also measured. The measured values and analysis methods are shown in Table 2.

Table 2. Elemental composition of the sludge powder

\begin{tabular}{llll}
\hline Measurement & Symbol/uni & Measured & Analytical method \\
\hline
\end{tabular}




\begin{tabular}{|c|c|c|c|}
\hline item & $\mathrm{t}$ & value & \\
\hline Carbon & $\mathrm{C}_{\mathrm{d}}(\%)$ & 37.64 & Methods for the determination of carbon and hydrogen in \\
\hline Hydrogen & $\mathrm{H}_{\mathrm{d}}(\%)$ & 5.18 & coal GB/T476-2008 three-section furnace method \\
\hline Oxygen & $\mathrm{O}_{\mathrm{d}}(\%)$ & 20.34 & $\begin{array}{l}\text { According to the } \mathrm{M}_{\mathrm{d}}, \mathrm{A}_{\mathrm{d}}, \mathrm{C}_{\mathrm{d}}, \mathrm{H}_{\mathrm{d}}, \mathrm{N}_{\mathrm{d}}, \mathrm{S}_{\mathrm{td}} \text { equivalent } \\
\text { calculation }\end{array}$ \\
\hline Nitrogen & $\mathrm{N}_{\mathrm{d}}(\%)$ & 6.01 & $\begin{array}{l}\text { Determination of nitrogen in coal GB/T19227-2008 } \\
\text { half-trace kelvin method }\end{array}$ \\
\hline Sulfur & $\mathrm{S}_{\mathrm{t}, \mathrm{d}} / \%$ & 0.87 & $\begin{array}{l}\text { Determination of total sulfur in coal GB/ T214-2007 } \\
\text { coulometric titration method }\end{array}$ \\
\hline
\end{tabular}

The x-ray diffraction analyzer (Model:D/MAX2200, Beijing Lihua Saisi Technology Co., Ltd.; Japan Rigaku product agent) was used to determine the mineral composition of the sludge powder. The results are shown in Fig. 2.

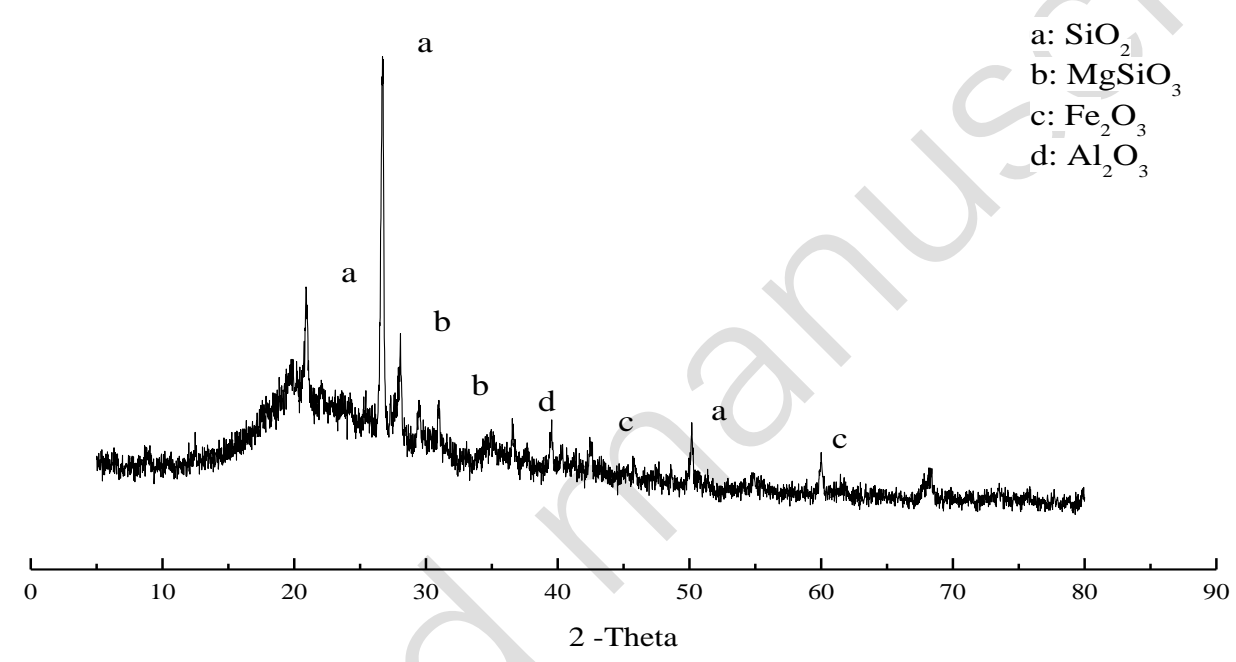

Figure 2. Mineral constituents of sludge powder

\subsection{Pyrolysis thermal analysis of the gradient final-temperature sludge}

The gradient final-temperature pyrolysis thermal analysis was carried out using a synchronous thermal analyzer (Model: TGA/DSC1/1600, Mettler Toledo) in an inert atmosphere (Pure $\mathrm{N}_{2}$ ) of the equivalent mass sludge powder. The final gradient temperatures were $200{ }^{\circ} \mathrm{C}, 250{ }^{\circ} \mathrm{C}, 300{ }^{\circ} \mathrm{C}, 350{ }^{\circ} \mathrm{C}$, and $400{ }^{\circ} \mathrm{C}$, heating rate $20^{\circ} \mathrm{C} / \mathrm{min}$, holding temperature $30 \mathrm{~min}$ (Hong et al., 2008; Penghui et al., 2015; Yiqie et al., 2015) The corresponding TGA/DSC curves are shown in Fig. 4, 6, 8, 10, and 12 .

\subsection{NMR analysis of the sludge pyrolysis products under gradient final temperature}

A fully digital NMR spectrometer (AVANCE400MHZ, Bruker switzerland ltd.) was used to analyze the forms in which the organic functional groups occur in the sludge powder at $200{ }^{\circ} \mathrm{C}, 250{ }^{\circ} \mathrm{C}, 300{ }^{\circ} \mathrm{C}, 350{ }^{\circ} \mathrm{C}$, and $400{ }^{\circ} \mathrm{C}$, respectively. (Note: the carbonization degree shift of the wave peak of the sludge pyrolysis products under the final temperature of $450{ }^{\circ} \mathrm{C}$ was exactly the same as that under the final temperature of $400{ }^{\circ} \mathrm{C}$, only the relative strength was reduced. Thus, $400{ }^{\circ} \mathrm{C}$ was selected as the maximum temperature of the final-temperature gradient). The corresponding NMR spectra are shown in Fig. 3, 5, 7, 9, 11, and 13. Among them, due to the complexity of the organic structure of the sludge powder, the peaks of the organic functional groups with a larger content tend to block those of the organic functional groups with smaller contents (see Fig. 3), thus, the analysis is reduced. Because there are fewer organic functional groups in the 
pyrolysis products of the high-end-temperature sludge than in the low-final-temperature sludge, the NMR spectrum inversion method from high to low-end-temperature could be used. Comparing the increase and decrease in the organic functional groups at the two final temperatures before and after, the types of organic functional groups released were analyzed. If there is some organic functional group release, the original functional group must be included in the original sludge, and then, we determine whether it has reducing properties. Finally, the release temperature range of the gradient final-temperature sludge was studied with the results of the pyrolysis thermal analysis (Hongrui et al., 2017; Jianhua and Qigong, 2001; Xingchu, 1960).

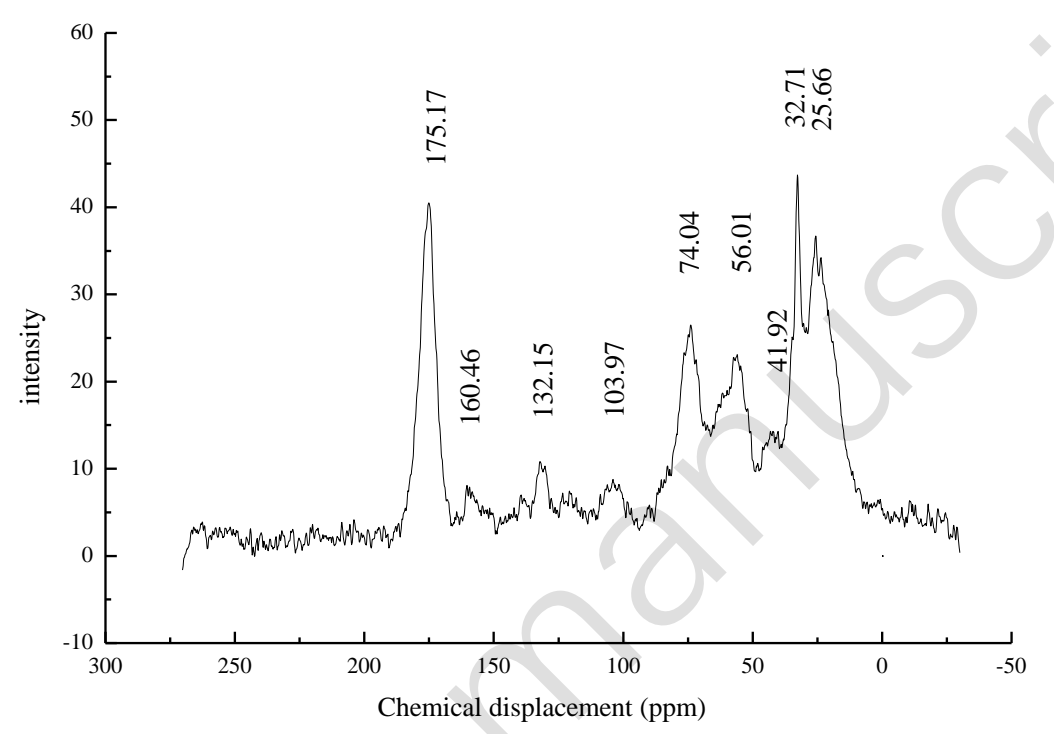

Figure 3. NMR spectrum of the sludge powder

\section{Results and discussion}

\subsection{Analysis of reducing groups in the pyrolysis products of the sludge at a final temperature of $400{ }^{\circ} \mathrm{C}$}

Fig. 4 shows the TGA/DSC curve of the pyrolysis of the sludge at the final temperature of $400{ }^{\circ} \mathrm{C}$. As shown in the figure, the weight loss of this final-temperature sludge was performed in two steps. In the first step, weight loss was $3.22 \%$ and the maximum rate of weight loss at $123.16^{\circ} \mathrm{C}$ was $0.82 \mathrm{mg} / \mathrm{min}$. The peak area (heat absorption) corresponding to the DSC curve was $-19.67 \mathrm{~J} / \mathrm{g}$. According to the above thermal analysis data, it can be inferred that the weight loss in the first step is a water volatilization process. In the second step, the weight loss was $46.17 \%$, and the rate of weight loss attained its maximum $(3.30 \mathrm{mg} / \mathrm{min})$ at $350.48{ }^{\circ} \mathrm{C}$. Also, the peak area (heat absorption) corresponding to the DSC curve was $-318.50 \mathrm{~J} / \mathrm{g}$. A comprehensive analysis of the second step of weightlessness showed the release of organic matter. 


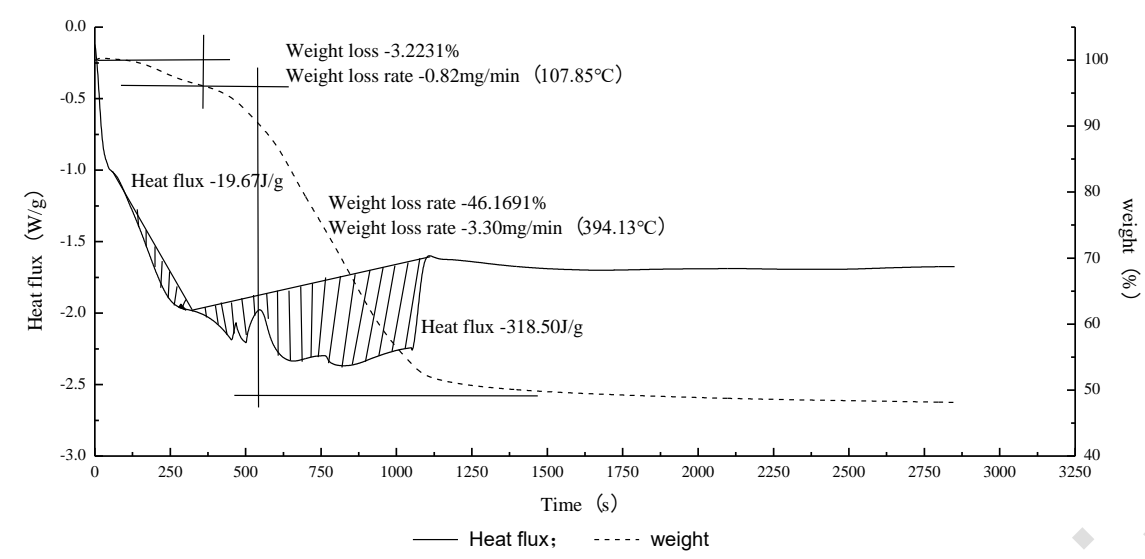

Figure 4. TGA/DSC curve of the sludge thermal decomposition at the final temperature of $400{ }^{\circ} \mathrm{C}$

Fig. 5 shows the NMR spectrum of pyrolysis products of the sludge at a final temperature of $400{ }^{\circ} \mathrm{C}$. It can be observed from the figure that the NMR spectrum of the sludge pyrolysis products at this final temperature has fewer peaks, longer distances, and no peak superposition. The chemical shifts of the carbon corresponding to the two peaks are 129.26 and $20.96 \mathrm{ppm}$, respectively. With the standard chemical shift of carbon element as the origin, the chemical shift of the measured compound proton and its distance, that is, the chemical shift of the carbon, expressed in ppm, is a nonfactor parameter $\left(1 \mathrm{ppm}=1 \times 10^{-6}\right)$. According to the chemical shift table of carbon in organic compounds, when the chemical shift of carbon is $129.26 \mathrm{ppm}$, the pyrolysis products of sludge at the final temperature of $400{ }^{\circ} \mathrm{C}$ may contain isothiocyanate and isocyanate, aromatics, and cyclic olefins, etc. When the shift is $20.96 \mathrm{ppm}$, the pyrolysis products of sludge at $400{ }^{\circ} \mathrm{C}$ may contain such organic groups as $\mathrm{CH}_{3} \mathrm{~S}-, \mathrm{CH}_{3}$-halogen, $\mathrm{RCH}_{2}-$ Halogen, $\mathrm{R}_{2} \mathrm{CH}-$ halogen, and cyclopropane.

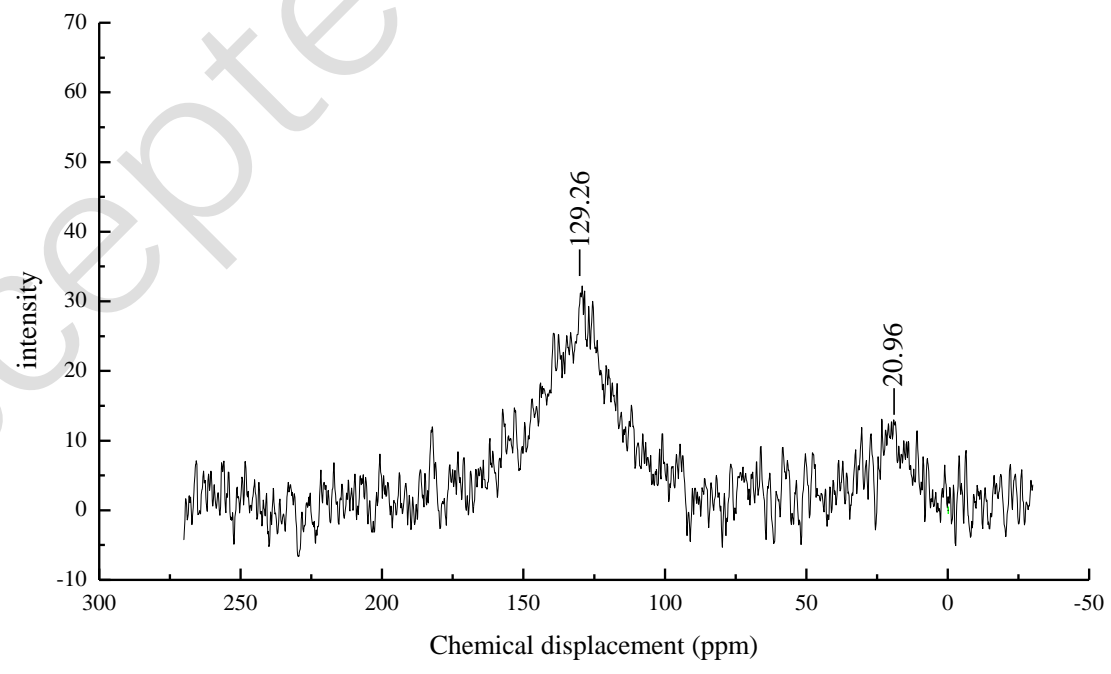

Figure 5. NMR spectrum of the sludge thermal decomposition products at $400{ }^{\circ} \mathrm{C}$ 
Fig. 6 depicts the TGA/DSC curve of the pyrolysis of the sludge at the final temperature of $350{ }^{\circ} \mathrm{C}$. It can be observed from the figure that the weight loss of this final-temperature sludge was also obtained in two steps. The dehydration weight loss in the first step was $3.62 \%$ and the maximum rate of weight loss at $123.16^{\circ} \mathrm{C}$ was $0.67 \mathrm{mg} / \mathrm{min}$. The peak area (heat absorption) corresponding to the DSC curve is $-66.08 \mathrm{~J} / \mathrm{g}$. In the second step, the weight loss was $39.77 \%$, and the weight loss rate reached a maximum of $2.86 \mathrm{mg} / \mathrm{min}$ at $282.44{ }^{\circ} \mathrm{C}$. The peak area corresponding to the DSC curve (heat absorption) is $-311.74 \mathrm{~J} / \mathrm{g}$, which also indicates the release process of organic matter.

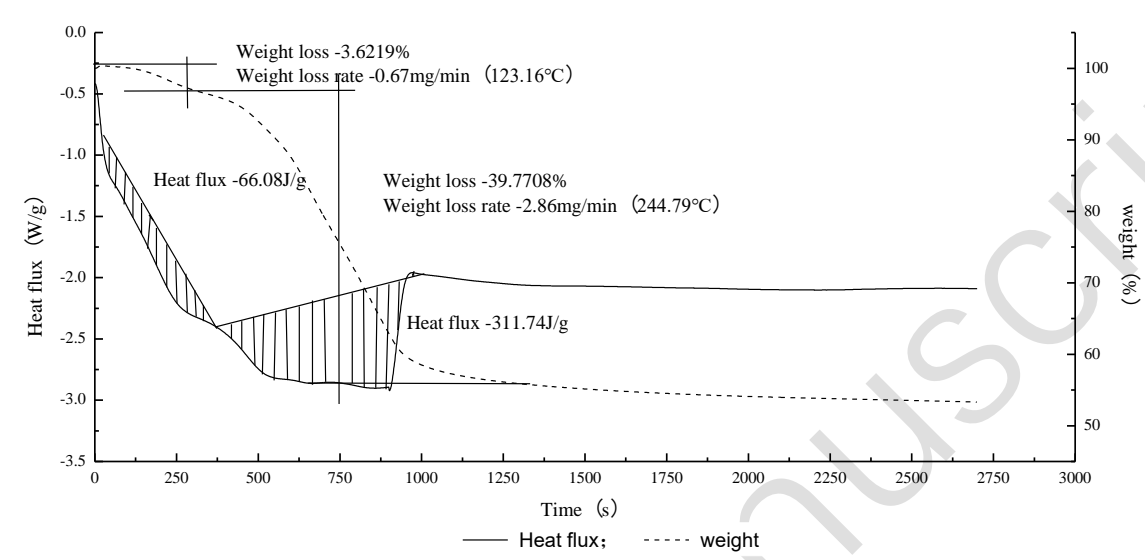

Figure 6. TGA/DSC curve of sludge thermal decomposition at the final temperature of $350{ }^{\circ} \mathrm{C}$

Fig. 7 shows the NMR spectrum of the sludge pyrolysis products at the final temperature of $350{ }^{\circ} \mathrm{C}$. Comparing with Fig. 4, it can be observed that there are NMR peaks at $350{ }^{\circ} \mathrm{C}$ and $400{ }^{\circ} \mathrm{C}$ final temperatures before and after the chemical shift of carbon at $129 \mathrm{ppm}$ with almost no change in intensity. This indicates that there was no release of organic functional groups in the temperature range of $350-400{ }^{\circ} \mathrm{C}$. NMR peaks are observed at 15.59, 23.47, and $30.68 \mathrm{ppm}$ of carbon chemical shift. According to the chemical shift table of carbon of organic compounds, organic functional groups such as $\mathrm{CH}_{3} \mathrm{~S}_{-}, \mathrm{CH}_{3}$-halogen, $\mathrm{RCH}_{2}-$ halogen, and cyclopropyl hydrocarbon may exist at $15.59 \mathrm{ppm}$. At $23.47 \mathrm{ppm}$, organic functional groups such as $\mathrm{CH}_{3} \mathrm{~S}-, \mathrm{CH}_{3}-$ halogen, $\mathrm{RCH}_{2}-$ halogen, $\mathrm{R}_{2} \mathrm{CH}-$ halogen, cyclopropyl hydrocarbon, $\mathrm{CH}_{3} \mathrm{~N}=$, and $\mathrm{RCH}_{2}-\mathrm{S}-$ may exist. Also, organic functional groups such as $\mathrm{CH}_{3}$-halogen, $\mathrm{RCH}_{2}$-halogen, $\mathrm{R} 2 \mathrm{CH}$-halogen, cyclopropyl hydrocarbon, $\mathrm{CH}_{3} \mathrm{~N}=$, and $\mathrm{RCH}_{2}-\mathrm{S}-$ may exist at $30.68 \mathrm{ppm}$. The NMR spectra of the sludge pyrolysis products at the final temperatures of $350{ }^{\circ} \mathrm{C}$ and $400{ }^{\circ} \mathrm{C}$ were extensively compared. It was found that in the temperature range of $350-400{ }^{\circ} \mathrm{C}, \mathrm{CH}_{3} \mathrm{~N}=$ and $\mathrm{RCH}_{2}-\mathrm{S}$ - were all released in the pyrolysis process, thus, the original sludge must contain these two functional groups. The two functional groups are hydrocarbon groups with reductive properties (Battiston et al., 2003; Mihaylov, 2004; Schmieg et al., 2004). Comparing the TGA/DSC curves of the pyrolysis at the final temperatures of $350{ }^{\circ} \mathrm{C}$ and $400{ }^{\circ} \mathrm{C}$, it was found that the weight loss and the heat absorption increased by $6.3983 \%$ and $6.76 \mathrm{~J} / \mathrm{g}$, respectively. This provides a reference for the calculation of the release amount and enthalpy of $\mathrm{CH}_{3} \mathrm{~N}=$ and $\mathrm{RCH}_{2}-\mathrm{S}-$ organic functional groups in the temperature range of $350-400^{\circ} \mathrm{C}$. 


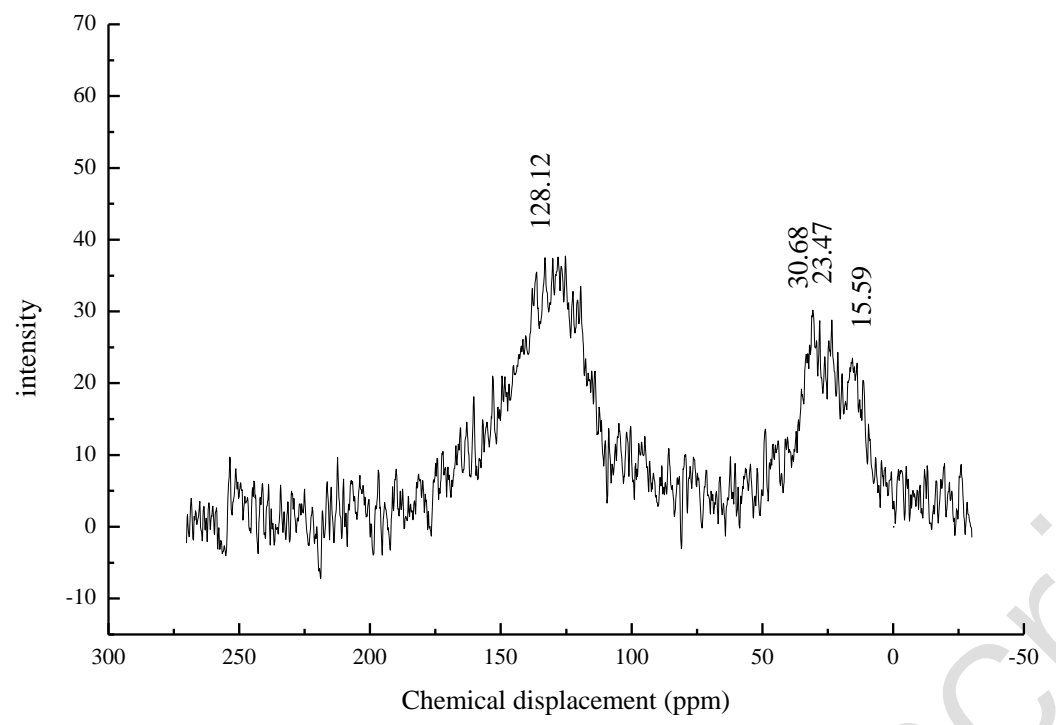

Figure 7. NMR spectrum of the sludge thermal decomposition products at $350{ }^{\circ} \mathrm{C}$

3.3 Analysis of the reducing groups in pyrolysis products of the sludge at a final temperature of $300{ }^{\circ} \mathrm{C}$

Fig. 8 shows the TGA/DSC curve of pyrolysis the sludge at the final temperature of $300{ }^{\circ} \mathrm{C}$. It can be observed from the figure that the weight loss of the final-temperature sludge is also determined in two steps. The dehydration weight loss in the first step was $2.88 \%$ and the maximum rate of weight loss was 0.44 $\mathrm{mg} / \mathrm{min}$, which occurred at $112.81{ }^{\circ} \mathrm{C}$. The peak area (heat absorption) corresponding to the DSC curve is $-27.65 \mathrm{~J} / \mathrm{g}$. The weight loss in the second step was $29.22 \%$, and the rate of weight loss rate reached a maximum of $2.57 \mathrm{mg} / \mathrm{min}$ at $282.47^{\circ} \mathrm{C}$. The peak area corresponding to the DSC curve (heat absorption) is $-292.53 \mathrm{~J} / \mathrm{g}$, which still indicates the release process of organic matter.

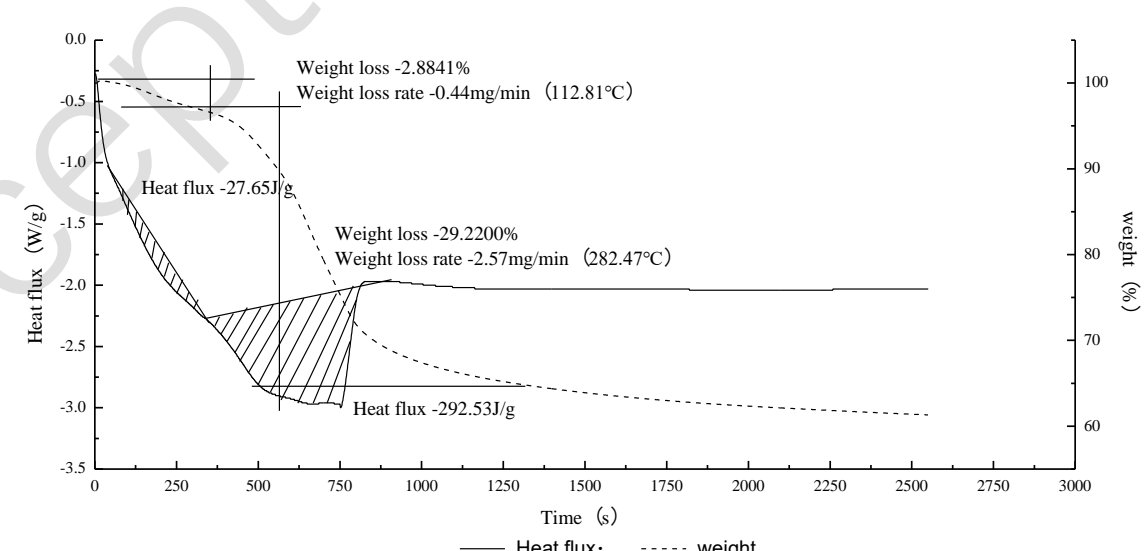

Figure 8. TGA/DSC curves of the sludge thermal decomposition at the final temperature of $300{ }^{\circ} \mathrm{C}$

Fig. 9 shows the NMR spectrum of the pyrolysis products of the sludge at the final temperature of $300{ }^{\circ} \mathrm{C}$. Comparing with Fig. 7, it can be observed that at the chemical shifts of carbon of 15.79, 23.84, and 30.48 ppm, there is a slight change in the chemical shift of carbon at the peaks. The chemical shifts at the peaks of 23.84 and $30.48 \mathrm{ppm}$ significantly increased the intensity of the two peaks. It can be inferred that the organic 
functional groups, $\mathrm{CH}_{3} \mathrm{~N}=$ and $\mathrm{RCH}_{2}-\mathrm{S}-$, were also released in the temperature range of $300-350{ }^{\circ} \mathrm{C}$. The chemical shift of carbon is 120.15 ppm NMR peaks appear. According to the chemical shift table of organic compounds carbon, carbodiimide, and cyanate may be present at $120.15 \mathrm{ppm}$. A comprehensive comparison of the NMR spectra of the sludge pyrolysis products at the final temperatures of $300{ }^{\circ} \mathrm{C}$ and $350{ }^{\circ} \mathrm{C}$ shows that, in the temperature range of $300-350{ }^{\circ} \mathrm{C}$, carbodiimide and cyanate were released in the pyrolysis process. At this temperature range, the NMR crest of the carbonized degree shift disappeared, thus, the two organic compounds must be contained in the original sludge, but it is not reductive (Battiston et al., 2003; Mihaylov, 2004; Schmieg et al., 2004). Comparing the TGA/DSC curves of the sludge at $300{ }^{\circ} \mathrm{C}$ and $350{ }^{\circ} \mathrm{C}$, it can be observed that the weight loss and heat absorption increased by $10.5508 \%$ and $19.21 \mathrm{~J} / \mathrm{g}$, respectively, which further proves that more organic functional groups were released between $300{ }^{\circ} \mathrm{C}$ and $350{ }^{\circ} \mathrm{C}$ but the reducing groups were still $\mathrm{CH}_{3} \mathrm{~N}=$ and $\mathrm{RCH}_{2}-\mathrm{S}-$.

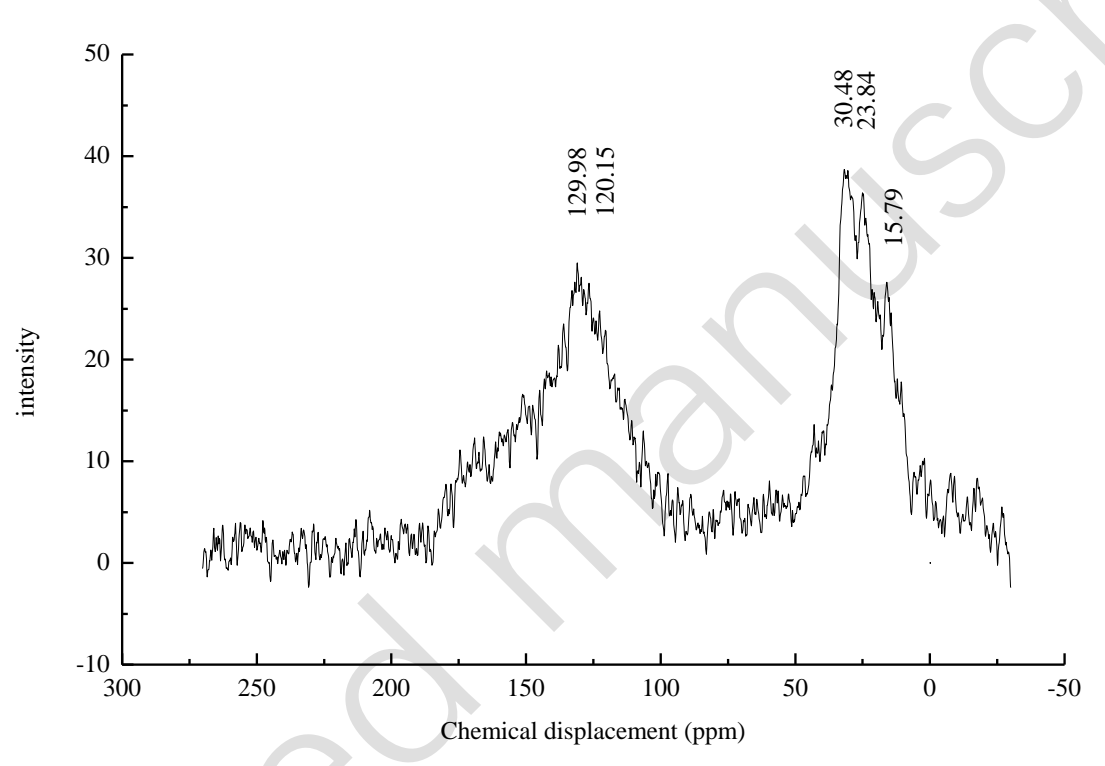

Figure 9. NMR spectrum of the sludge thermal decomposition products at $300{ }^{\circ} \mathrm{C}$

3.4 Analysis of the reducing groups in pyrolysis products of sludge at a final temperature of $250{ }^{\circ} \mathrm{C}$

Fig. 10 shows the TGA/DSC curve of the pyrolysis of the sludge at the final temperature of $250{ }^{\circ} \mathrm{C}$. It can be observed from the figure that the weight loss of the sludge is also determined in two steps. In the first step, the dehydration weight loss was $3.29 \%$. The maximum rate of weight loss of $0.52 \mathrm{mg} / \mathrm{min}$ was realized at $117.43{ }^{\circ} \mathrm{C}$ and the peak area (heat absorption) corresponding to the DSC curve is $-23.10 \mathrm{~J} / \mathrm{g}$. The weight loss in the second step was $16.68 \%$ and the maximum rate of weight loss at $228.80^{\circ} \mathrm{C}$ is $2.15 \mathrm{mg} / \mathrm{min}$. The peak area corresponding to the DSC curve (heat absorption) is $-180.27 \mathrm{~J} / \mathrm{g}$, which still indicates the release process of organic matter. 


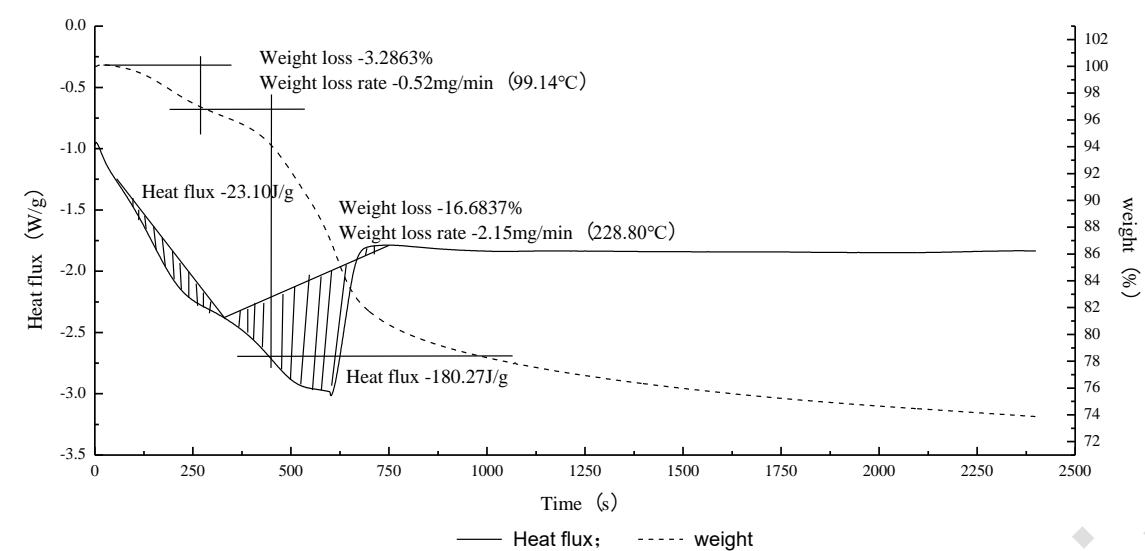

Figure 10. TGA/DSC curve of the sludge thermal decomposition final temperature of $250{ }^{\circ} \mathrm{C}$

Fig. 11 shows the NMR spectrum of the sludge pyrolysis products at a final temperature of $250{ }^{\circ} \mathrm{C}$. Comparing with Fig. 8, NMR peaks are observed at carbon chemical shifts of 172.88, 73.92, and $56.41 \mathrm{ppm}$. According to the degree shift table of carbonization of organic compounds, such organic compounds as carboxylic acid and its derivatives and thiourea could be present at $172.88 \mathrm{ppm}$. At $73.92 \mathrm{ppm}$, organic functional groups such as $\mathrm{CH}_{3}-$ halogen, $\mathrm{R}_{2} \mathrm{CH}-\mathrm{O}-, \mathrm{R}_{3} \mathrm{CN}=, \mathrm{R}_{3} \mathrm{C}-\mathrm{O}$-, and cycloalkynes could be present. Organic functional groups such as $\mathrm{RCH}_{2}-$ halogen, $\mathrm{R}_{2} \mathrm{CH}-$ halogen, $\mathrm{CH}_{3} \mathrm{O}-, \mathrm{RCH}_{2}-\mathrm{N}=, \mathrm{RCH}_{2}-\mathrm{O}-, \mathrm{R}_{2} \mathrm{CH}-\mathrm{N}$ $=, \mathrm{R}_{2} \mathrm{CH}-\mathrm{S}-, \mathrm{R}_{3} \mathrm{C}-$ halogen, and $\mathrm{R}_{3} \mathrm{CS}-$ may also be present at $56.41 \mathrm{ppm}$. With a comprehensive comparison of the sludge at the final temperatures of $250{ }^{\circ} \mathrm{C}$ and $300{ }^{\circ} \mathrm{C}$. The NMR spectrum of the pyrolysis products of sludge at room temperature shows that the NMR peaks of the chemical shifts of carbon of 172.88, 73.92, and $56.41 \mathrm{ppm}$ disappeared in the temperature range of $250{ }^{\circ} \mathrm{C}$ to $300{ }^{\circ} \mathrm{C}$ and organic carboxylic acids and their derivatives, thiourea, organic functional group, including $\mathrm{R}_{2} \mathrm{CH}-\mathrm{O}-, \mathrm{R}_{3} \mathrm{CN}=, \mathrm{R}_{3} \mathrm{CO}-$, cycloalkyne, $\mathrm{CH}_{3} \mathrm{O}-$, $\mathrm{RCH}_{2}-\mathrm{N}=, \mathrm{RCH}_{2}-\mathrm{O}-, \mathrm{R}_{2} \mathrm{CH}-\mathrm{N}=, \mathrm{R}_{2} \mathrm{CH}-\mathrm{S}-, \mathrm{R}_{3} \mathrm{C}-$ halogen, and $\mathrm{R}_{3} \mathrm{CS}-$, disappeared in the pyrolysis process. Therefore, it is deduced that the original sludge contained these organics and organic functional groups, among which cyclic alkynes, $\mathrm{RCH}_{2}-\mathrm{N}=, \mathrm{RCH}_{2}-\mathrm{O}-, \mathrm{R}_{2} \mathrm{CH}-\mathrm{N}=, \mathrm{R}_{2} \mathrm{CH}-\mathrm{S}-$, and other hydrocarbons were organic groups with reductive properties.

There is a slight change in the chemical shift of the NMR peaks between the carbon chemical shift of 15 and $35 \mathrm{ppm}$, but the peak shape and intensity remain almost unchanged. Therefore, it was inferred that the reductive groups, $\mathrm{CH}_{3} \mathrm{~N}=$ and $\mathrm{RCH}_{2}-\mathrm{S}$-, were not released in the temperature range of $250{ }^{\circ} \mathrm{C}$ to $300{ }^{\circ} \mathrm{C}$. Comparing the TGA/DSC curves of the sludge pyrolysis at the final temperatures of $250{ }^{\circ} \mathrm{C}$ and $300{ }^{\circ} \mathrm{C}$, it was obtained that the weight loss and the heat absorption increased by $12.5363 \%$ and $112.26 \mathrm{~J} / \mathrm{g}$, respectively. At this stage, the increase in weight loss was the largest, and the sudden increase in heat absorption further proves that many types of organic functional groups were released in the temperature range of $250{ }^{\circ} \mathrm{C}$ to $300^{\circ} \mathrm{C}$. 


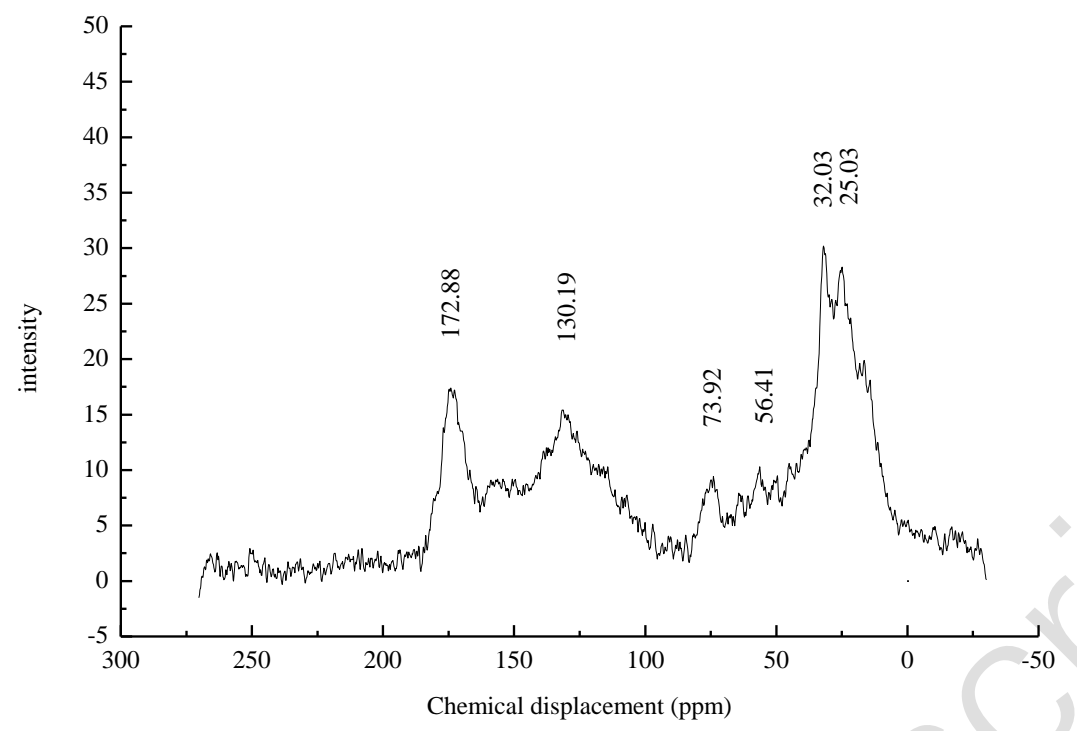

Figure 11. NMR spectrum of sludge thermal decomposition products at $250{ }^{\circ} \mathrm{C}$

\subsection{Analysis of reducing groups in the sludge pyrolysis products at $200^{\circ} \mathrm{C}$ final temperature}

Fig. 12 shows the TGA/DSC curve of the pyrolysis of the sludge at the final temperature of $200{ }^{\circ} \mathrm{C}$. It can be observed from the figure that the weight loss of the final-temperature sludge is still determined in two steps. The dehydration weight loss in the first step was $3.43 \%$ and the maximum weight loss rate at $105.37^{\circ} \mathrm{C}$ was $0.56 \mathrm{mg} / \mathrm{min}$. The peak area (heat absorption) corresponding to the DSC curve is $-32.22 \mathrm{~J} / \mathrm{g}$. The weight loss in the second step was $5.83 \%$ and the maximum weight loss rate at $217.83{ }^{\circ} \mathrm{C}$ was $1.04 \mathrm{mg} / \mathrm{min}$. The peak area corresponding to the DSC curve (heat absorption) is $-112.64 \mathrm{~J} / \mathrm{g}$, which still indicates the release process of organic matter.

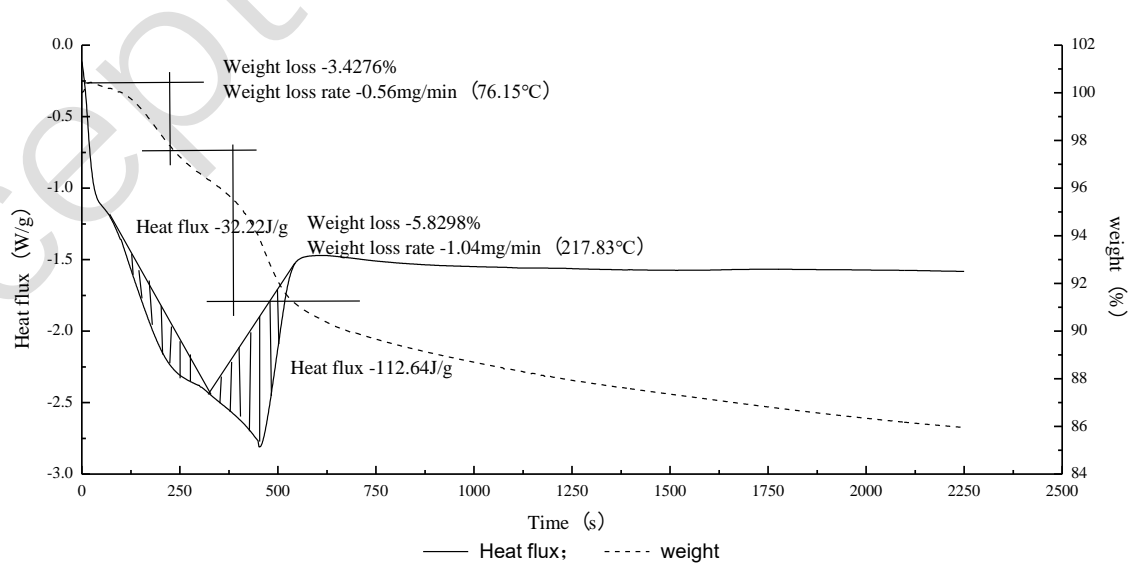

Figure 12. TGA/DSC curves of sludge thermal decomposition at the final temperature of $200{ }^{\circ} \mathrm{C}$

Fig. 13 shows the NMR spectrum of the sludge pyrolysis products at a final temperature of $200{ }^{\circ} \mathrm{C}$. Comparing with Fig. 10, it can be observed that the NMR peaks appeared at 41.95 and $103.36 \mathrm{ppm}$ of carbon chemical shift. According to the chemical shift table of carbon of organic compounds, such organic functional groups as $\mathrm{CH}_{3}$-halogen, $\mathrm{RCH}_{2}$-halogen, $\mathrm{R}_{2} \mathrm{CH}$-halogen, $\mathrm{R}_{3} \mathrm{CN}=, \mathrm{RCH}_{2}-\mathrm{N}=, \mathrm{R}_{3} \mathrm{C}$-halogen, and 
cyclopropane may exist at $41.95 \mathrm{ppm}$. On the other hand, organic functional groups such as cyclic olefins and aromatics may exist at $103.36 \mathrm{ppm}$. A comprehensive comparison of the NMR spectra of sludge pyrolysis products at the final temperatures of $200{ }^{\circ} \mathrm{C}$ and $250{ }^{\circ} \mathrm{C}$ shows that in the temperature range from $250{ }^{\circ} \mathrm{C}$ to $300{ }^{\circ} \mathrm{C}$, the NMR peaks of carbonization degree shift of 41.95 and $103.36 \mathrm{ppm}$ disappeared. As the above functional groups may exist in the sludge pyrolysis products at higher final temperatures, it is impossible to determine whether they are released and their occurrence in the original sludge. Because there was no much change between the NMR spectrum of the sludge pyrolysis products and that of the sludge powder at the final temperature of $200{ }^{\circ} \mathrm{C}$, there was no need for further analysis. Comparing the TGA/DSC curves of the sludge pyrolysis at the final temperatures of $200{ }^{\circ} \mathrm{C}$ and $250{ }^{\circ} \mathrm{C}$, it was found that the weight loss and the heat absorption increased by $10.85 \%$ and $67.63 \mathrm{~J} / \mathrm{g}$, respectively. One step proved the release of organic functional groups in the temperature range of $200-250{ }^{\circ} \mathrm{C}$.

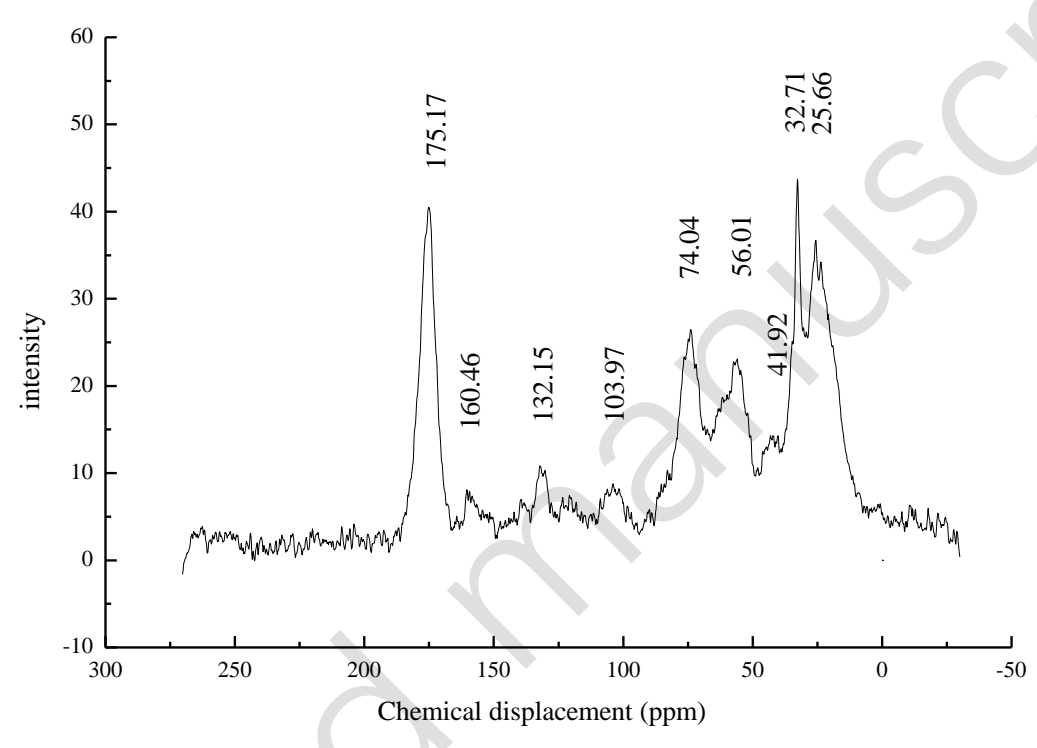

Figure 13. NMR spectrum of sludge thermal decomposition products at $200{ }^{\circ} \mathrm{C}$

\section{Conclusion}

From the results of this study, we draw the following conclusions.

(1) The reductive groups in sludge mainly exist in the form of hydrocarbons. It was obtained that the organic functional groups existing in the original sludge include $\mathrm{CH}_{3} \mathrm{~N}=, \mathrm{RCH}_{2}-\mathrm{S}-, \mathrm{RCH}_{2}-\mathrm{N}=, \mathrm{RCH}_{2}-\mathrm{O}-, \mathrm{R}_{2} \mathrm{CH}-$ $\mathrm{N}=, \mathrm{R}_{2} \mathrm{CH}-\mathrm{S}-$, and cycloalkynes. These reductive groups obtained in this experiment can convert $\mathrm{NO}_{\mathrm{X}}$ into $\mathrm{N}_{2}$ and achieve denitration.

(2) The structure of the functional group that may be converted into $\mathrm{HCN}$ is $\mathrm{CH} 3 \mathrm{~N}=, \mathrm{RCH} 2-\mathrm{N}=, \mathrm{R} 2 \mathrm{CH}-\mathrm{N}=$, the main release interval is $300 \sim 400^{\circ} \mathrm{C}$; the structure of the functional group that may be converted to $\mathrm{NH} 3$ is $\mathrm{CH} 3 \mathrm{~N}=, \mathrm{RCH} 2-\mathrm{N}=, \mathrm{R} 2 \mathrm{CH}-\mathrm{N}=$, the main release interval is $300 \sim 400^{\circ} \mathrm{C}$; the structure of the functional group that may be converted to $\mathrm{CO}$ is $\mathrm{CH} 3 \mathrm{~N}=$, RCH2-S-, RCH2-N=, RCH2-O-, R2CH-N=, R2CH-S-, the main release interval is $300 \sim 400^{\circ} \mathrm{C}$; the structure of the functional group that may be converted to $\mathrm{CH} 4$ is $\mathrm{CH} 3 \mathrm{~N}=$, $\mathrm{RCH} 2-\mathrm{S}-, \mathrm{RCH} 2-\mathrm{N}=, \mathrm{R} 2 \mathrm{CH}-\mathrm{N}=, \mathrm{R} 2 \mathrm{CH}-\mathrm{S}-\mathrm{The}$ main release interval is $300 \sim 400^{\circ} \mathrm{C}$. 
(3) In the temperature range of $250-300{ }^{\circ} \mathrm{C}$, the sludge has the largest increase in weight loss and heat absorption and the most organic functional groups are released, including cycloalkyne, $\mathrm{RCH}_{2}-\mathrm{N}=, \mathrm{RCH}_{2}-\mathrm{O}-$, $\mathrm{R}_{2} \mathrm{CH}-\mathrm{N}=, \mathrm{R}_{2} \mathrm{CH}-\mathrm{S}-$, and other organic groups with reducing properties. Thermo gravimetric analysis and nuclear magnetic resonance analysis and detection are echoed. The time when the thermal explanatory release of the functional group is the most is also the time when the organic matter is pyrolyzed the most. Therefore, this temperature range is the optimal temperature range for sludge reburning and denitration.The release temperature range of the reducing groups, $\mathrm{CH}_{3} \mathrm{~N}=$ and $\mathrm{RCH}_{2}-\mathrm{S}-$, in the sludge is $300-400{ }^{\circ} \mathrm{C}$, and in the range of $350 \sim 400{ }^{\circ} \mathrm{C}$, only two kinds of reducing groups are released.

(4) The organic structure of the sludge is complex and the peak shapes of the functional groups easily appear when directly analyzed by nuclear magnetic resonance, which affects the accuracy of the analysis. The appropriate temperature gradient was selected and the nuclear magnetic resonance spectrum inversion method from the high-end temperature to the low-end temperature was adopted. Comparing the increase and decrease in the organic functional groups at the two final temperatures before and after the chemical shift, the forms in which the organic functional groups occur in the original sludge can be determined based on the release of organic functional groups. If the gradient temperature difference is reduced, the accuracy of the analysis can be further improved.

\section{Credit authorship contribution statement}

Kang Yang: Conceptualization, Funding acquisition. Hui Li: Formal analysis, Investigation. Fang Dang: Methodology, Writing-review \& editing. Ji Zou: Methodology, Writing-review \& editing. Songzhu Zhang: Methodology, Writing-review \& editing. Kang Yang and Hui Li contributed equally to this work.

\section{Declaration of competing interest}

The author(s) declare no competing interests.

\section{Acknowledgment}

This work was supported by the Annual Key Scientific Research Program of Shaanxi Provincial Education Department (Collaborative Innovation Center Project) [grant numbers 20JY041] and the Qingyuan Science and Technology Plan Project [Grant Number 2020KJJH040].

\section{References}

Chen, Y.Z., He, L., Guan, Y.L., Lu, H.W., Li, J. (2017). Life cycle assessment of greenhouse gas emissions and water-energy optimization for shale gas supply chain planning based on multi-level approach: Case study in Barnett, Marcellus, Fayetteville, and Haynesville shales. Energy Conversion and Management, 134, 382-398.

Dong, L., Chengwei, W., Liuping, C. (2007). Study on solid nuclear magnetic resonance in the process of low-temperature oxidation of Daming coal. J. Shenzhen Univ. (Science and Technology Edition), 8.

Feng, S.S., Lu, H.W., Tian, P.P., Xue, Y.X., Lu, J.Z., Tang, M., Feng, W. (2020). Analysis of microplastics in a remote region of the Tibetan Plateau: Implications for natural environmental response to human activities. The Science of the Total Environment, 739, 140087.

He, L., Shen, J., Zhang, Y. (2018). Ecological vulnerability assessment for ecological conservation and environmental management. Journal of Environmental Management, 206, 1115-1125.

Hong, L., Suping, C., Wei, T., Yali, W., Xia, W., Ke, L. (2008). Study on sludge characteristics and disposal methods. Environ. Eng., 26, 63-66. 
Hongrui, M., Ling, C., Jiangjun, Z., Xiangpping, C., Chao, Z. (2017). Analysis of chromium and its exolifenation morphology in low-molecular organic acid-immersed tannery sludge. Environ. Eng., 35, 121-124.

Jianhua, C., Qigong, D. (2001). The Principle and Analysis of the Spectrum vol 3, Science Press.

Lipeng, H., Guanjie, L., Jiandong, Z., Jian, S., Liyong, W., Yi, Z., An, G. (2018). Research on NOxUltra-Low Emission in CFB Boiler with Sludge Co-Combustion, Application of Energy technology, 21-26.

Penghui, Y., Jun, W., Chengtun, Q. (2015). Extended oil-bearing sludge vacuum Pyretolysis study. Environmental Engineering, 33, 101-103.

Xingchu, Q., 1960, Chemical Analysis Manual, Chemical Industry Press, Beijing.

Yiqie, D., Haijun, L., Qian, Z., Xiaoyun, L. (2015). Release and thermal effect of antixix fermentation leachate pollutants in municipal sludge. Environ. Eng., 54-58.

Zhiqiang, W., Hua, T., Jinsheng, Z. (2010). Application analysis of desiccation sludge reburning technology to reduce NOx Emission. Power Station System Engineering, 26, 30-32.

Zhiqiang, W., Hua, T., Jinsheng Z. (2010). Application analysis of reducing NO_x emissions by reburning dried sludge. Power Station System Engineering, 26, 31.

Dong, L., Tianle, Z., Runwei, L., et al. (2016). Effects of co-processing sewage sludge in cement kiln on NOx, NH3 and PAHs emissions. Chemosphere, 159: 595-601.

Ping, F., Zijun, T., Xiang, X., et al. (2019). Using sewage sludge as a flue gas denitration agent for the cement industry: factor assessment and feasibility. Journal of Cleaner Production, 224: 292-303.

Xiang, X., Ping, F., Jianhang, H., et al. (2019). Mechanistic study on NO reduction by sludge reburning in a pilot scale cement precalciner with different CO2 concentrations. RSC Advances, 9, 22863-22874.

Weiyi, F., Tianle, Z., Yifei, S., et al. (2014). Effects of gas compositions on NOx reduction by selective non-catalytic reduction with ammonia in a simulated cement precalciner atmosphere. Chemosphere, 113: 182-187.

Ping, F., Zijun, T., Jianhang, H., et al. (2015). Using sewage sludge as a denitration agent and secondary fuel in a cement plant: a case study. Fuel Processing Technology, 137: 1-7.

Sheng, S., Peisheng, L., Xuexin, S., et al. (2004). Basic characteristics of sludge and thermogravimetric study of co-firing with coal. Thermal Power Generation, 69-71+74-85.

Xiuru, L., Qinggang, L., Ke, Z. (2010). Research on pyrolysis characteristics and kinetics of municipal sewage sludge. Thermal Energy and Power Engineering, 25, 677-680+690.

Huan, J., Baoxia, L., Cheng J. (2014). Characteristics of gas and solid phase products of sludge pyrolysis in different temperature ranges. CIESC Journal, 65, 2316-2322.

Zhichao, G., Yanjun, H., Yingjie Z. (2012). Study on the pyrolysis characteristics and kinetics of municipal sewage sludge under different heating rates. Environmental Pollution and Control, 34,35-39. 